\title{
Blood Lipids and Leptin Levels in Patients with Ischemic Heart Disease and Concomitant Non-Alcoholic Fatty Liver Disease after Treatment with Atorvastatin
}

\author{
Yevgen Sklyarov, Nataliya Karpyshyn*
}

\begin{abstract}
Non-alcoholic fatty liver disease which is regarded as an independent predictor of cardiovascular diseases plays a significant role in the development of ischemic heart disease. In patients with verified ischemic heart disease, hyperleptinemia causes hypertrophy of vascular smooth muscle cells, increases the synthesis of endothelial growth factor as well as the accumulation of reactive oxygen species in the vascular wall and leads to elevated expression of endothelin-1, which is also an indicator of its influence on vascular remodeling. Leptin is a predictor of a higher functional class of angina pectoris and heart rhythm disorders; it may be used as an indirect marker of systemic inflammation as well. Pathogenic basis for ischemic heart disease treatment is hypolipidemic therapy with statins as the medications of choice; in addition to basic hypolipidemic action, they improve endothelial function increasing nitric oxide synthesis possessing anti-inflammatory, anti-ischemic, antiaggregatory, antithrombotic and profibrinolytic action, as well as antioxidant and antiproliferative effects.

The objective of the research was to study changes in blood lipids and leptin levels in patients with ischemic heart disease and concomitant non-alcoholic fatty liver disease after a course of atorvastatin.

Materials and methods. 54 patients with ischemic heart disease and concomitant non-alcoholic fatty liver disease were examined; there were 26 individuals who did not take atorvastatin and 28 individuals taking atorvastatin at a dose of $40 \mathrm{mg}$ per day for 3 months. All the patients underwent anthropometry, determination of blood lipids, leptin and liver transaminase levels, electrocardiography, echocardiography, ultrasound of the internal organs.

Results. A significant decrease in the average level of total cholesterol $(p<0.01)$, concentration of low-density lipoproteins $(p<0.01)$ and leptin level $(p<0.01)$ was detected in patients after 3 months of atorvastatin use. Moreover, there was detected a direct correlation between leptin level and triglyceride concentration, leptin level and the body mass index, leptin level and waist circumference, leptin level and hip circumference, as well as a high correlation between total cholesterol and low-density lipoproteins, and total cholesterol and the body mass index.

Conclusions. The administration of atorvastatin to patients with ischemic heart disease and concomitant non-alcoholic fatty liver disease at a dose of $40 \mathrm{mg}$ per day improves the patients' general condition and promotes a significant decrease in the levels of pro-atherogenic fractions of blood lipids and leptin level, as well as promotes the reduction in risk factors for comorbid pathology and prevents the occurrence of its complications.
\end{abstract}

\section{Keywords}

ischemic heart disease; atorvastatin; leptin; non-alcoholic fatty liver disease

Danylo Halytsky Lviv National Medical University, Lviv, Ukraine

*Corresponding author: robak.nata@ukr.net

\section{Problem statement and analysis of the recent research}

Non-alcoholic fatty liver disease (NAFLD) which is regarded as an independent predictor of cardiovascular diseases plays a significant role in the development of ischemic heart disease (IHD) $[1,3,5]$. In patients with IHD, the coexistence of NAFLD significantly increases the signs of ischemia and the incidence of ventricular rhythm disturbances, worsens the indices of autonomic regulation of cardiac activity, slows down their improvement and accelerates the atherosclerotic pro- cess in the myocardium according to data of spiral computer tomography $[2,8]$.

Numerous experimental and clinical investigations showed that adipocyte hormones such as leptin, adiponectin and resistin play an important role in the regulation of liver lipid metabolism and NAFLD pathogenesis [7, 10]; however, hyperleptinemia is an independent risk factor for the development of infarction and stroke [4].

In patients with verified IHD, hyperleptinemia causes hypertrophy of vascular smooth muscle cells, increases the synthesis of endothelial growth factor as well as the accumulation 
of reactive oxygen species in the vascular wall and leads to elevated expression of endothelin-1, which is also an indicator of its influence on vascular remodeling [9]. Leptin is a predictor of a higher functional class of angina pectoris and heart rhythm disorders; it may be used as an indirect marker of systemic inflammation as well since the reduction in its level implies a more frequent reduction in c-reactive protein [6].

Pathogenic basis for IHD treatment is hypolipidemic therapy. The medications of choice are statins which reduce cholesterol synthesis in the liver by means of competitive inhibition of HMG-CoA reductase [12]. In addition to basic hypolipidemic action, statins improve endothelial function increasing nitric oxide synthesis possessing anti-inflammatory (decreasing hs-CRP concentration, reducing secretion of interleuki 6 , tumor necrosis factor), anti-ischemic, antiaggregatory, antithrombotic and profibrinolytic action, as well as antioxidant and antiproliferative effects [13].

The objective of the research was to study changes in blood lipids and leptin levels in patients with IHD and concomitant NAFLD after a course of atorvastatin.

\section{Materials and methods}

54 patients with ischemic heart disease and concomitant nonalcoholic fatty liver disease were examined. They were divided into 2 groups: Group I included 26 individuals who did not take atorvastatin, Group II included 28 individuals taking atorvastatin at a dose of $40 \mathrm{mg}$ per day for 3 months.

All the patients underwent anthropometry, determination of blood lipids, leptin and liver transaminase levels, electrocardiography, echocardiography, ultrasound of the internal organs.

Anthropometric measurements of height and body weight calculating the body mass index (BMI) (Quetelet index): BMI=weight $(\mathrm{kg}) /$ height $\left(\mathrm{m}^{2}\right)$ were performed in all the patients.

The diagnosis of IHD was made based on the results of coronarography, past myocardial infarction or positive treadmill test.

According to the guidelines of the International Diabetes Federation (2005), to diagnose abdominal obesity, the waist circumference (WC) was measured at the level of the umbilicus and assessed using the criteria for men WC $>94 \mathrm{~cm}$ and women $\mathrm{WC}>80 \mathrm{~cm}$.

Blood lipids were estimated based on the serum levels of total cholesterol (TC), triglycerides (TG), low-density lipoprotein (LDL) cholesterol and high-density lipoprotein (HDL) cholesterol. The activity of serum alanine transaminase (ALT) and aspartate aminotransferase (AST) was determined using standard methods. Serum leptin level was determined using enzyme immunoassay test by means of spectrophotometer "Stat-fax 1200", diagnostic set of reagents (DRG International, USA), ELISA test ("sandwich test").

Ultrasonography of the hepatobiliary system was performed on an empty stomach using Philips HDI 1500 ul- trasound machine with a $3.5 \mathrm{mHz}$ scanning sensor. The following parameters were determined: the size of hepatic lobes, hepatic parenchyma density, the degree of fatty infiltration of the liver, the presence of fibrosis and the diameter of the vena portae (VP). Fatty infiltration of the liver was diagnosed in case of enlarged liver, diffuse homogeneous increase in its echogenicity, distal shadowing and dilated vena portae.

The efficacy of prescribed treatment was evaluated before and after the 3-week therapy using atorvastatin at a dose of $40 \mathrm{mg}$ a day.

The obtained results were processed in Microsoft Excel using the Student's t-test and the Pearson correlation analysis.

\section{Results and Discussion}

Among the patients of Group I, there were 13 (50.0\%) males and $13(50.0 \%)$ females. The average age was $59.9 \pm 2.13$ years. Among the patients of Group II, there were $21(75.0 \%)$ males and $7(25.0 \%)$ females. The average age was $58.8 \pm 1.15$ years (Table 1). When assessing the anthropometric indices in patients of Group I, the average BMI constituted $32.2 \pm 0.65$ $\mathrm{kg} / \mathrm{m}^{2}$, while in patients of Group II it was $30.4 \pm 0.77 \mathrm{~kg} / \mathrm{m}^{2}$. In patients of Group I, the average index of waist circumference constituted $111.0 \pm 1.7 \mathrm{~cm}$, hip circumference constituted $101.8 \pm 1.99 \mathrm{~cm}$, waist-to-hip ratio was $1.1 \pm 0.02$. In patients of Group II, the average index of waist circumference constituted $103.9 \pm 1.27 \mathrm{~cm}$, hip circumference constituted $96.5 \pm 1.51 \mathrm{~cm}$, waist-to-hip ratio was $1.1 \pm 0.01$.

The comparison of the anthropometric data in patients with IHD and concomitant NAFLD did not reveal a reliable difference in age and anthropometric indices between patients who did not take atorvastatin and those taking atorvastatin, which indicated homogeneity of sampling.

Dyslipidemia, hypercholesterolemia with several cases of the increase in ALT and AST were observed in all patients with the given comorbidity.

3 months after administration of atorvastatin in complex therapy for IHD and stable angina with concomitant NAFLD the improvement of general condition was observed in the group of patients taking atorvastatin which was manifested as a reduction in the complaints concerning the cardiovascular system.

The comparison of blood lipids levels in patients of Group I and Group II revealed a pronounced hypolipidemic effect which was accompanied by a reliable decrease in the average level of cholesterol from $6.1 \pm 0.19 \mathrm{mmol} / \mathrm{l}$ to $4.30 \pm 0.16$ $\mathrm{mmol} / \mathrm{l}(\mathrm{p}<0.01)$ and concentration of LDL cholesterol from $4.10 \pm 0.19 \mathrm{mmol} / \mathrm{l}$ to $2.30 \pm 0.17 \mathrm{mmol} / \mathrm{l}(\mathrm{p}<0.01)$ in the group of patients taking atorvastatin for 3 months (Table 2). At the same time, reliable changes in TG $(\mathrm{p}>0.05)$ and HDL cholesterol ( $p>0.05)$ levels were not detected. Thus, after administration of atorvastatin, a distinct tendency toward the reduction in the levels of cholesterol and LDL cholesterol on the background of slight changes in the levels of HDL cholesterol and TG was observed. 
Table 1. Distribution of patients by age and sex

\begin{tabular}{ll|c|c|c}
\hline & Indices, unit of measurement & Group I $(\mathrm{n}=26)$ & Group II $(\mathrm{n}=28)$ & Reliability of the difference, $\mathrm{p}$ \\
\hline Age, years & $59.9 \pm 2.13$ & $58.8 \pm 1.15$ & $>0.05$ \\
\hline BMI, $\mathrm{kg} / \mathrm{m}^{2}$ & $32.2 \pm 0.65$ & $30.4 \pm 0.77$ & $>0.05$ \\
\cline { 2 - 4 } & Waist circumference, $\mathrm{cm}$ & $111.0 \pm 1.7$ & $103.9 \pm 1.27$ & $<0.01$ \\
\hline Hip circumference, $\mathrm{cm}$ & $101.8 \pm 1.99$ & $96.5 \pm 1.51$ & $<0.05$ \\
\cline { 2 - 4 } Note. & $1.1 \pm 0.02$ & $1.1 \pm 0.01$ & $>0.05$ \\
\cline { 2 - 4 } & Waist-to-hip ratio & &
\end{tabular}

$\mathrm{n}-$ the number of patients in the group

Table 2. Blood lipids levels in patients with IHD and concomitant NAFLD who took and did not take atorvastatin (M \pm m)

\begin{tabular}{l|c|c|c}
\hline Indices & Group I (n=26) & Group II $(\mathrm{n}=28)$ & Reliability of difference, $\mathrm{p}$ \\
\hline TC, mmol/l & $6.1 \pm 0.19$ & $4.30 \pm 0.16$ & $<0.01$ \\
\hline LDL cholesterol, mmol/l & $1.1 \pm 0.04$ & $1.20 \pm 0.04$ & $>0.05$ \\
\hline HDL cholesterol, mmol/l & $4.10 \pm 0.19$ & $2.30 \pm 0.17$ & $<0.01$ \\
\hline TG, mmol/l & $1.9 \pm 0.12$ & $1.7 \pm 0.16$ & $>0.05$ \\
\hline
\end{tabular}

Note.

$\mathrm{n}$ - the number of patients in the group

The analysis of correlations in the group of patients taking atorvastatin for 3 months revealed a high correlation between cholesterol and LDL ( $\mathrm{r}=0.90)$, cholesterol and BMI $(\mathrm{r}=0.40)$. A positive correlation was observed between TG and LDL $(\mathrm{r}=0.41)$, BMI and LDL $(\mathrm{r}=0.40)$.

On the background of long-term intake of atorvastatin at a dose of $40 \mathrm{mg}$, the level leptin decreased significantly from $37.8 \pm 4.76 \mathrm{ng} / \mathrm{ml}$ to $15.6 \pm 2.58 \mathrm{ng} / \mathrm{ml}$ indicating leptinreducing effect of this drug (Table 3 ). At the same time, a significant reduction in ALT level after atorvastatin intake $(\mathrm{p}<0.05)$ was detected, while AST level did not differ significantly, although there was a tendency to its reduction.

The analysis of correlations detected a positive relation between leptin and TG levels ( $r=0.50)$, leptin level and the BMI $(\mathrm{r}=0.57)$. The correlation was noticed between leptin level and waist circumference ( $\mathrm{r}=0.50)$, leptin level and hip circumference $(r=0.49)$ as well. Thus, the reduction in leptin level after treatment with atorvastatin results in the reduction in TG level, the BMI, hip and waist circumferences, respectively.

Thus, the obtained data showed a positive effect of atorvastatin on both pro-atherogenic modified fractions of blood lipids and the inhibition of leptinemia; it reduces risk factors for IHD and NAFLD development thereby preventing the incidence of complications.

\section{Conclusions}

- The administration of atorvastatin to patients with IHD and concomitant NAFLD at a dose of $40 \mathrm{mg}$ per day improves the patients' general condition and promotes a significant decrease in the levels of pro-atherogenic fractions of blood lipids.
- The administration of atorvastatin to patients with IHD and concomitant NAFLD at a dose of $40 \mathrm{mg}$ per day leads to a significant reduction in leptin level.

- The reduction in leptin level after intake of atorvastatin in patients with IHD and NAFLD promotes the improvement of the patients' general condition as well as the reduction in risk factors for comorbid pathology and prevents the occurrence of its complications.

\section{Prospects for further research}

Prospects for further research are to study the effect of atorvastatin on dynamics of changes in adiponectin and resistin levels in patients with IHD and concomitant NAFLD after hypolipidemic therapy with atorvastatin.

\section{References}

[1] Babak OYa, Kolesnikova EV. Nealkogolnaya zhirovaya bolezn pecheni i kardiovaskularnyy risk: sovremennyy vzglyad na problemu. Optimizatsiya terapii. Novosti meditsiny i farmatsii. 2012;8:33-38

[2] Bazylevych AYa. Influence of ursodeoxycholic acid treatment upon ischemia and arrhythmia incidence, and autonomous nervous heart regulation in the patients with postinfarction cardiosclerosis after coronary arteries bypass graft combined with non-alcoholic fatty liver disease. Praktychna medytsyna. 2011;17(2):103-109

[3] Ivachevska VV, Chopey IV. Otsinka yakosti zhyttia patsientiv iz poiednanym perebihom nealkoholnoii zhyrovoii 
Table 3. Leptin and liver transaminase levels in patients with IHD and concomitant NAFLD depending on atorvastatin intake $(\mathrm{M} \pm \mathrm{m})$

\begin{tabular}{l|c|c|c}
\hline Indices & Group I $(\mathrm{n}=26)$ & Group II $(\mathrm{n}=28)$ & Reliability of difference, $\mathrm{p}$ \\
\hline Leptin, $\mathrm{ng} / \mathrm{ml}$ & $37.8 \pm 4.76$ & $15.6 \pm 2.58$ & $<0.01$ \\
\hline ALT, $\mathrm{mcmol} / \mathrm{l}$ & $0.60 \pm 0.06$ & $0.50 \pm 0.03$ & $<0.05$ \\
\hline AST, mcmol/l & $0.40 \pm 0.3$ & $0.30 \pm 0.02$ & $>0.05$ \\
\hline
\end{tabular}

Note.

$\mathrm{n}$ - the number of patients in the group

khvoroby pechinky ta stabilnymy formamy ishemichnoii khvoroby sertsia. Hastroenterolohiia. 2014;3:35-37

[4] Kovaleva YuO. Interaction activity of inflammatory process and leptin in patients with ischemic heart diseases associated with obesity. Experym klin med. 2010;3:93-97

[5] Kolesnikova EV. Nonalcoholicfatty liver disease and hypertension: what have we achieved in the understanding of the problem. Ukr med chasopys. 2014;3:61-66

[6] Kutayni AR, Taschuk VK. Dynamika rivniv leptynu ta stan koronarnoho i funktsionalnoho rezrviv y khvorykh na stabilnu stenokardiiu. Kiln eksperym patolohiia. 2012;2:76-80

[7] Ognyeva OV. Relationship of the adipokines and their influence on the liver functional state in patients with nonalcoholic fatty liver disease, type 2 diabetes mellitus and at their combination. Suchasna hastroenterol. 2014;6:7-14

[8] Perepelchenko NA, Zyryanov BN, Lvova IA, Matveeva EL. Chy vplyvaie porushennia vuhlevodnoho ta lipidnoho obminu na rozvytok kaltsynozu koronarnykh sudyn. Liky Ukraiiny. 2015;1:45-51

[9] Urbanovych AM, Suslyk HI. Rol leptynu v rozvytku ishemichnoii khvoroby sertsia u khvorykh na tsukrovyi diabet 2-ho typu z ozhyrinniam. Eksperymentalna ta klinichna fiziolohiia i biokhimiia. 2014;2:56-62

[10] Chumak AA, et al. Molecular mechanism features in development of nonalcoholic fatty liver disease. Ukraiinkyi medychnyi chasopys. 2013;6(98):33-40

[11] Area M, Pigna G. Treating statin-intolerant patients. Diabets Metab Syndr Obes. 2011;4:155-166

[12] Athyros VG, Tziomalos K, Gossios TD, et al. Safety and efficacy of long-term statin treatment for cardiovascular events in patients with coronary heart disease and abnormal liver tests in the Greek Atorvastatin and Coronary Heart Disease Evaluation (GREACE) Study: a post-hoc analysis. Lancet. 2010;376(9756):1916-1922. DOI: http:// doi.org/10.1016/S0140-6736(10)61272-X
[13] Kavalipati N, Shah J, Ramakrishan A, Vasnawala H. Pleiotropic effects of statins. Indian Journal of Endocrinology and Metabolism. 2015;19(5):554-562

Received: 29 November 2016

Revised: 5 December 2016

Accepted: 23 December 2016 